\title{
The fatty acid content in the tissues of broiler chickens fed diets containing a brown-seed linseed var. Opal or the yellow-seed var. Linola
}

\author{
J. Barteczko and F. Borowiec
}

\author{
Cracow Agricultural University, \\ Department of Animal Nutrition \\ Al. Mickiewicza 24/24, 30-059 Kraków, Poland
}

\begin{abstract}
Six groups of broiler chickens, 18 each, were fed from the first day of life to slaughter at the age of 7 weeks on wheat-soyabean diets supplemented with fat in the amount of $34 \mathrm{~g} / \mathrm{kg}$ diet. The sources of fat were: rape seed oil, soyabean oil, a mixture of rape seed and soyabean oils, full-fat seeds of a brown-seed variety of linseed, Opal, or the yellow-seed variety Linola; the control diet was not supplemented with fat. Opal linseed contained (in \% of total fatty acids) 15.9 linoleic acid (C 18:2 $\mathrm{n}-6$ ) and $72.8 \alpha$-linolenic acid (C 18:3 n-3); the secds of the Linola variety contained, respectively, $5 \mathrm{i} .5$ and $\mathrm{I} .8$. After slaughter, the breast muscle and abdominal fat were taken from 5 chickens in each group. In the birds fed the diet with Opal linseeds, the PUFA n-6/n-3 ratio was 3.1 in breast muscle lipids and 1.1 in abdominal fat, whereas the same ratios in the birds fed the diet with Linola seeds was 24.3 and 23.6, while in the control birds, 28 and 15.5. Adding Linola linseeds to diets for broiler chickens cannot be recommended as a means of improving the nutritional value of broiler meat tissues.
\end{abstract}

KEY WORDS: broiler chickens, linsced, fatty acids, breast muscle, abdominal fat

\section{INTRODUCTION}

The fatty acid profile in the body lipids of broiler chickens depends to a large extent on the composition of the fat contained in feed mixtures (Smulikowska et al., 1990; Barteczko and Kamiński, 1995). The addition of linseed increases the energy concentration in feeds and makes it possible to cover essential fatty acid requirements (Pinchasov and Nir, 1992; Barowicz et al., 1997; Niemiec et al., 1999; Borowiec et al., 2001). Due to their high $\alpha$-linolenic acid (C 18:3n- 3) con- 
tent, the addition of traditional varieties of linseed to feeds for broilers leads to a reduction in the $n-6 / n-3$ ratio of fatty acids (FA) in feeds and broiler tissues. This may be advantageous for the health of poultry consumers, since a large excess of n-6 fatty acids in human diets is associated with the occurrence of numerous diseases (Barteczko et al., 1993; Kulasek and Bartnikowska, 1994; Singer, 1995). New varieties of linseed have been developed recently. They have yellow seeds and a modified fatty acid composition (Borowiec et al., 2001).

The objective of this study was to determine the effect of adding a brown-seed variety of linseed, Opal, and a yellow-seed variety, Linola ${ }^{\mathrm{TM}} 947$, to diets, on the fatty acid profile and relative proportions of fatty acids in the lipids of the breast muscle and abdominal fat of broiler chickens.

\section{MATERIAL AND METHODS}

The study was conducted on Starbro broilers in six groups, 18 birds in each. From weeks 2 to 7 of life, the broilers were housed under standard conditions, individually in metabolic cages fitted with individual feeders and automatic drinkers. The birds were fed ad libitum with complete feeds, with $21 \%$ crude protein, according to Nutrient Requirements of Poultry (1996). The main components of the diets were wheat and soyabean meal, all of the feeds also contained $8 \%$ meat meal. The control feed (1) was not supplemented with fat, the remainder was supplemented with $3.4 \%$ fat in the form of: diet 2 , a $1: 1$ mixture of rape seed and soyabean oils; diet 3 , rape seed oil; diet 4 , soyabean oil; diet 5 , seeds of the brownseed variety of linseed, Opal ( $7 \%$ of the diet); dict 6 , seeds of the yellow-seed linseed variety, Linola ${ }^{\mathrm{TM}} 947$ ( $7 \%$ of the diet). The metabolizable energy content in the diets for the experimental groups (2-6) was similar and equaled from 2980 to $2993 \mathrm{kcal} \mathrm{AME} / \mathrm{kg}$; the energy content in the control group (1) was lower and equaled $2806 \mathrm{kcal} \mathrm{AME} / \mathrm{kg}$. The diets were prepared weekly and fed in dry form.

The final body weight of the chickens ranged from 2206 in the control group to 2221-2365 g in the experimental groups. After completing 7 weeks of life, 5 chickens from each group were decapitated and the left breast muscle and abdominal fat were sampled. The samples were placed in plastic bags and stored at $-18^{\circ} \mathrm{C}$ until analysis. The tissues from individual birds were homogenized and lipids were extracted by the method of Folch et al. (1957). The fatty acid profile was determined in the feed fats, diets, and tissue lipids using a Varian $3400 \mathrm{CX}$ gas chromatograph equipped with a FID detector (the carrier gas was argon, the column, DB-23, column temperature, $100-205^{\circ} \mathrm{C}$, sample injector, $200^{\circ} \mathrm{C}$, detector, $240^{\circ} \mathrm{C}$ ).

The results were subjected to statistical analysis using one-way analysis of variance. The Duncan test was used to determine the significance of differences between means for groups. 


\section{RESULTS}

The fatty acid contents in the brown-seed variety Opal and the yellow-seed Linola were, respectively (in \% of total FA): saturated FA (SFA) 9.7 and 10.9, unsaturated FA (UFA) 90.2 and 89.0, monounsaturated FA (MUFA) 22.7 and 14.3, polyunsaturated FA (PUFA) 67.4 and 74.7. The PUFA n-6 to PUFA n-3 ratio was 0.31 in the Opal variety, and 40 in Linola, since the Opal and Linola varieties contained, respectively (in \% of total FA): 15.9 and 51.5 linoleic acid (C18:2n-6) and 72.8 and $1.8 \alpha$-linolenic acid (C18:3n-3).

Table 1 shows the profile of fatty acids in the diets ( $\%$ of total acids). The addition of vegetable fat lowered the SFA content of the fat in the experimental diets in comparison with the control. In the diets with $7 \%$ brown-seed Opal and

TABLE 1

Fatty acid (FA) composition of experimental diets, \% total FA

\begin{tabular}{lcccccc}
\hline & \multicolumn{6}{c}{ Diet no/source of added fat } \\
\cline { 2 - 7 } Fatty acids & 1 & 2 & 3 & 4 & 5 & 6 \\
\cline { 2 - 7 } & control & $\begin{array}{c}\text { rape seed } \\
\text { oil+soya oil }\end{array}$ & $\begin{array}{c}\text { rape secd } \\
\text { oil }\end{array}$ & soya oil & $\begin{array}{c}\text { linseed } \\
\text { cv. Opal }\end{array}$ & $\begin{array}{c}\text { linseed cv. } \\
\text { Linola }\end{array}$ \\
\hline SFA & 27.34 & 17.56 & 15.78 & 19.12 & 13.78 & 14.56 \\
UFA & 72.66 & 82.44 & 84.22 & 80.88 & 86.22 & 85.44 \\
MUFA & 29.34 & 37.53 & 48.11 & 26.55 & 27.42 & 23.90 \\
PUFA & 43.32 & 44.91 & 36.11 & 54.33 & 58.80 & 61.54 \\
UFA:SFA & 2.65 & 4.68 & 5.33 & 4.21 & 5.99 & 5.85 \\
MUFA:SFA & 1.07 & 2.13 & 3.04 & 1.38 & 1.99 & 1.64 \\
PUFA:SFA & 1.58 & 2.55 & 2.28 & 2.83 & 4.26 & 4.21 \\
PUFA n-6/n-3 & 2.58 & 3.09 & 2.00 & 5.02 & 0.71 & 5.78 \\
\hline
\end{tabular}

SFA - total saturated FA, UFA - total unsaturated FA, MUFA - total monounsaturated FA, PUFA total polyunsaturated $\mathrm{FA}$

yellow-seed Linola, the PUFA:SFA ratio was similar, but the change in the content of linoleic and $\alpha$-linolenic acid contents in the fat of linseed caused a change in the $\mathrm{n}-6 / \mathrm{n}-3$ PUFA ratio in the diet lipids; this ratio equaled 0.7 in the group 5 diet, as compared with 5.8 in the group 6 diet.

Table 2 presents the content of fatty acids in the lipids of the breast muscle of broilers. The addition of vegetable fat or linseeds to the diets increased $(\mathrm{P}<0.05)$ the UFA:SFA and PUFA:SFA ratios in lipids in comparison with the control group. The ratio of n-6 PUFA to n-3 PUFA was the highest in the group fed the control diet, followed by the diet with the addition of yellow-seed Linola and the group fed the diet with added soyabcan oil, it was the lowest in the group given the diet with the brown-seed Opal variety $(\mathrm{P}<0.01)$. 
TABLE 2

Fatty acid composition of lipids from breast muscle of broilers fed diets with various supplemental fats

\begin{tabular}{|c|c|c|c|c|c|c|}
\hline \multirow{3}{*}{ Fatty acids } & \multicolumn{6}{|c|}{ Group/source of added fat } \\
\hline & 1 & 2 & 3 & 4 & 5 & 6 \\
\hline & control & $\begin{array}{c}\text { rape seed } \\
\text { oil+soya oil }\end{array}$ & $\begin{array}{l}\text { rape seed } \\
\text { oil }\end{array}$ & soya oil & $\begin{array}{l}\text { linseed } \\
\text { Opal }\end{array}$ & $\begin{array}{l}\text { linseed } \\
\text { Linola }\end{array}$ \\
\hline SFA & $33.91^{\mathrm{b}}$ & $32.18^{b}$ & $29.76^{a}$ & $31.79^{a b b}$ & $32.55^{\mathrm{b}}$ & $31.80^{\mathrm{ab}}$ \\
\hline UFA & $63.24^{a}$ & $65.10^{\mathrm{ab}}$ & $70.25^{b}$ & $67.19^{\mathrm{h}}$ & $64.09^{\mathrm{a}}$ & $66.71^{\mathrm{b}}$ \\
\hline MUFA & $44.94^{\mathrm{d}}$ & $41.77^{\circ}$ & $50.07^{\circ}$ & $38.44^{\mathrm{b}}$ & $38.61^{\mathrm{b}}$ & $35.55^{a}$ \\
\hline PUFA & $18.30^{\circ}$ & $23.33^{\mathrm{c}}$ & $20.18^{\mathrm{b}}$ & $28.75^{\mathrm{e}}$ & $25.48^{d}$ & $31.16^{\mathrm{i}}$ \\
\hline UFA:SFA & $1.86^{\mathrm{a}}$ & $2.02^{b}$ & $2.36^{\mathrm{c}}$ & $2.11^{\mathrm{b}}$ & $1.96^{\mathrm{ab}}$ & $2.09^{\mathrm{b}}$ \\
\hline MUFA:SFA & $1.32^{\mathrm{b}}$ & $1.29^{\mathrm{b}}$ & $1.68^{c}$ & $1.2 !^{a b}$ & $1.18^{\mathrm{a}}$ & $1.11^{\mathrm{a}}$ \\
\hline PUFA:SFA & $0.54^{a}$ & $0.72^{\mathrm{bc}}$ & $0.68^{\mathrm{b}}$ & $0.90^{\mathrm{d}}$ & $0.78^{\mathrm{c}}$ & $0.98^{\circ}$ \\
\hline PUFA $n-6 / n-3$ & $28.0^{\mathrm{F}}$ & $14.1^{\mathrm{C}}$ & $9.8^{3}$ & $17.5^{\circ}$ & $3.1^{\mathrm{A}}$ & $24.3^{\mathrm{E}}$ \\
\hline
\end{tabular}

a.b.A.B - means in rows determined with different letters are significantly different at:

a.b $\mathrm{P}<0.05 ;{ }^{\mathrm{A} .}{ }^{\mathrm{B}} \mathrm{P}<0.01$

Table 3 presents the fatty acid content of abdominal fat of broilers (\% of total fatty acids). Similarly as in breast meat lipids, an increased ratio of UFA:SFA $(\mathrm{P}<0.05)$ and PUFA:SFA $(\mathrm{P}<0.01)$ was found in the birds fed diets supplemented with vegetable oils or linseed. The n-6 PUFA to n-3 PUFA ratio in abdominal fat was highest in the group given the diet with Linola seeds, followed by the control diet and the diet with soyabean oil. It was lowest in the group receiving the brownseed variety, Opal. All of the differences were highly significant $(\mathrm{P}<0.01)$.

TABLE 3

Fatty acid composition of lipids from abdominal fat of broilers fed diets with various supplemental fats

\begin{tabular}{lcccccc}
\hline & \multicolumn{5}{c}{ Group/source of added fat } \\
\cline { 2 - 7 } Fatty acids & 1 & 2 & 3 & 4 & 5 & 6 \\
\cline { 2 - 7 } & control & $\begin{array}{c}\text { rape seed } \\
\text { oil+soya oil }\end{array}$ & $\begin{array}{c}\text { rape seed } \\
\text { oil }\end{array}$ & soya oil & $\begin{array}{c}\text { linseed } \\
\text { Opal }\end{array}$ & $\begin{array}{c}\text { linseed } \\
\text { Linola }\end{array}$ \\
\cline { 2 - 7 } SFA & $34.89^{\mathrm{b}}$ & $29.77^{\mathrm{a}}$ & $28.04^{\mathrm{a}}$ & $29.11^{\mathrm{a}}$ & $27.75^{\mathrm{a}}$ & $29.12^{\mathrm{a}}$ \\
UFA & $64.71^{\mathrm{a}}$ & $69.92^{\mathrm{b}}$ & $71.53^{\mathrm{b}}$ & $70.51^{\mathrm{b}}$ & $71.80^{\mathrm{b}}$ & $70.56^{\mathrm{b}}$ \\
MUFA & $55.47^{\mathrm{b}}$ & $50.10^{\mathrm{b}}$ & $54.87^{\mathrm{c}}$ & $45.77^{\mathrm{a}}$ & $47.01^{\mathrm{b}}$ & $46.00^{\mathrm{a}}$ \\
PUFA & $9.24^{\mathrm{A}}$ & $19.82^{\mathrm{C}}$ & $16.66^{\mathrm{b}}$ & $24.74^{\mathrm{b}}$ & $24.79^{\mathrm{b}}$ & $24.56^{\mathrm{b}}$ \\
UFA:SFA & $1.85^{\mathrm{a}}$ & $2.35^{\mathrm{b}}$ & $2.55^{\mathrm{b}}$ & $2.42^{\mathrm{b}}$ & $2.58^{\mathrm{b}}$ & $2.42^{\mathrm{b}}$ \\
MUFA:SFA & $1.59^{\mathrm{a}}$ & $1.68^{\mathrm{a}}$ & $1.90^{\mathrm{b}}$ & $1.57^{\mathrm{a}}$ & $1.69^{\mathrm{a}}$ & $1.58^{\mathrm{a}}$ \\
PUFA:SFA & $0.26^{\mathrm{A}}$ & $0.66^{\mathrm{b}}$ & $0.59^{\mathrm{B}}$ & $0.85^{\mathrm{C}}$ & $0.89^{\mathrm{C}}$ & $0.84^{\mathrm{C}}$ \\
PUFA n-6/n-3 & $15.5^{\mathrm{F}}$ & $6.2^{\mathrm{C}}$ & $4.8^{\mathrm{B}}$ & $9.5^{\mathrm{D}}$ & $1.1^{\wedge}$ & $23.6^{\mathrm{F}}$ \\
\hline
\end{tabular}

- as in Table 2 


\section{DISCUSSION}

Manipulation of the fatty acid composition of feeds makes it possible to improve the nutritional value of poultry meat (Smulikowska et al., 1990; Barowicz et al., 1997). The results of this experiment indicate that adding linseed or vegetable oils to the diets of broilers significantly increases the proportion of unsaturated fatty acids, cspecially PUFA in relation to SFA in broiler meat tissues. On the other hand, when trying to change the proportion of n-6 PUFA to n-3 PUFA in poultry meat, the ratio of these acids in the feed lipids should be taken into consideration.

Opal linseed, has a fatty acid profile similar to traditional varieties, in which the $n-6$ to $n-3$ PUFA ratio is 0.31 . It therefore has a very favourable influence on the polyunsaturated fatty acid (n-3 PUFA) content in the lipids of broiler meat tissues. The yellow-seed linseed variety, Linola, which has a highly modified fatty acid composition in comparison with traditional varieties (the n-6 PUFA to $n-3$ PUFA ratio in this variety is 40 ), caused a substantial rise in the n-6 PUFA to n-3 PUFA ratio in breast meat lipids and abdominal fat of chickens to about 24 . This deteriorated the dietary value of meat, since in human diets, the n-6 PUFA to n-3 PUFA ratio should be 1-5 (Kulasek and Bartnikowska, 1994). In terms of the nutritional value of the meat tissues, supplementing the diets of broiler chickens with rape seed oil is more beneficial than using soyabean oil.

\section{CONCLUSIONS}

Linseed is a good energy supplement for the diets of broiler chickens and modifies the fatty acid profiles of tissue lipids. Given the nutritional value of meat tissues and the need to reduce the n-6 PUFA to n-3 PUFA ratio, supplementing the diets of broiler chicken with the seeds of traditional linseed varieties or rape seed oil is more beneficial than using soyabean oil or animal fat. The seeds of the Linola variety of linseed, due to their modified fatty acid profile, should not be used in poultry nutrition because they cause a substantial increase in the proportion of $n-6$ PUFA to n-3 PUFA in the tissue lipids of poultry.

\section{REFERENCES}

Barowicz T., Brzóska F., Pictras M., Gąsior R., 1997. Hipocholesterelemic effect of full-fat linseed in pigs diet (in Polish). Med. wet. 53, 164-167

Barteczko J., Wenk C., Prabucki A., 1993. Characteristic of systematic lipids in broiler chicks given feed supplemented with enzymatic preparations. Proceedings of 9th European Symposium on Poultry Nutrition, WPSA, Jelenia Góra (Poland), p. 386 
Barteczko J., Kamiński J., 1995. The effect of standarized dietary fats on body lipids and cholesterol fractions in plasma of broiler chickens. Proceedings of 10th European Symposium on Poultry Nutrition, WPSA, Antalya (Turkey), pp. 33-36

Borowicc F., Zając T., Micck P., Marciński M., 2001. Comparison of nutritive value of some new commercial linseed oil cultivars for ruminants. J. Anim. Feed Sci. 10, 301-308

Folch J., Lees M., Sloane S.G.H., 1957. A simple method for isolation and purification of total lipids from animal tissues. J. Biol. Chem. 226, 497-509

Kulasek G., Bartnikowska E., 1994. The importance of unsaturated fatty acids in nutrition of humans and animals (Part I). Feed sources, metabolism and requirement (in Polish). Mag. wet. 3, 39-44

Niemiec J., Stępińska M., Świerczewska E., Riede! J., Kakowska R., 1999. Effect of diet with oil seeds on laying hens performance and egg quality (in Polish). Oilseed Crops, Poznań (Poland), Vol, 20, 305-310

Nutrient Requirements of Pouttry. Nutritive Value of Feedstuffs (in Polish), 1996. $3^{\text {rd }}$ Edition. The Kielanowski Institute of Animal Physiology and Nutrition (Editor). Jabłonna (Poland)

Pinchasov Y., Nir J,, 1992. Effect of dietary polyunsaturated fatty acid concentration on performance, fat deposition, and carcass fatty acid composition in broiler chickens. Poultry Sci. 71, $1504-1512$

Singer P., 1995. Omega-3 Fettsauren. Fachbuch Ernährung. Umschau -Zeitschriftenverlag, Frank* furt (Germany)

Smulikowska S., Chibowska M., Wiśnjewska J., 1990. Effects of low glucosinolate rapeseed - raw, pressed or extracted on performance, thyroid status and fatty acid profile of broiler chickens. Proceedings of 8th European Poultry Conference, WPSA, Barcelona (Spain), Vol. 1, 348-351

\section{STRESZCZENIE}

Zawartość kwasów tluszczowych w tkankach kureząt brojlerów j̇ywionych mieszankami z dodatkiem nasion Inu oleistego brązowonasiennej odmiany Opal i żóltonasiennej odmiany Linola

Sześć grup kurcząt brojlcrów, po 18 ptaków w każdej, żywiono od pierwszego dnia życia do uboju w wicku 7 tygodni dietami pszenno-sojowymi uzupełnionymi tłuszczem w ilości $34 \mathrm{~g} / \mathrm{kg}$ diety. Źródłem tłuszczu były: olej rzepakowy, olej sojowy, mieszanina oleju rzcpakowcgo i sojowego, pełnotłuste nasiona lnu brązowonasiennej odmiany Opal lub żółtonasiennej odmiany Linola; do diety kontrolnej nie dodano thuszczu. Nasiona lnu odmiany Opal zawierały ( $w \%$ sumy kwasów tłuszczowych) 15,9 kwasu linolowego (C 18:2n-6) i 72,8 kwasu $\alpha$-linolenowego (C 18:3n-3), w nasionach odmiany Linola zawartość tych kwasów wynosiła odpowiednio 51,5 i 1,8. Po uboju 5 kurcząt z każdej grupy pobrano mięśnie piersiowe i łłuszcz sadełkowy. U ptaków żywionych dictą zawierającą nasiona lnu odmiany Opal stosunck PUFA n-6/n-3 wynosił 3,1 w thuszczu mięśni piersiowych i 1,1 w tłuszczu brzusznym; odpowiedni stosunek u ptaków żywionych dietą $z$ dodatkiem nasion !nu Linola wynosił 24,3 i 23,6, u ptaków żywionych dietą kontrolną 28 i 15,5. Wprowadzenie nasion Inu odmiany Linola do mieszanck nic może być zalecane w celu poprawy wartości dietetycznej tuszek kurcząt brojlerów. 